\title{
Non-intubated COVID-19 patients despite high levels of supplemental oxygen
}

\author{
Samuel Chosidow, Gaëtan Plantefève, Megan Fraissé, Hervé Mentec, Radj Cally and Damien Contou* (i)
}

Keywords: SARS-CoV-2, COVID-19, ICU, ARDS, Mechanical ventilation, Tracheal intubation, Acute respiratory failure, ICU

Many COVID-19 patients with acute hypoxemic respiratory failure may require invasive mechanical ventilation [1]. However, deciding whether and when a patient should be intubated is complex, especially in COVID-19 patients who commonly exhibit severe hypoxemia without clinical signs of respiratory failure (the so-called silent hypoxemia) [2]. While clinical signs of respiratory failure seem to be universally acknowledged as intubation criteria [3], their precise definition is lacking. Some authors have consequently used definite thresholds to guide intubation [4], but this approach is debated [5] as an individualized strategy may be more adequate. In our ICU, only COVID-19 patients showing persistent signs of respiratory distress associated with profound hypoxemia were intubated.

We therefore aimed (1) to assess the proportion of our COVID-19 patients not receiving invasive mechanical ventilation despite high levels of supplemental oxygen ( $\geq 15 \mathrm{~L} / \mathrm{min}$ for $\geq 6 \mathrm{~h}$ ) as well as (2) to describe their clinical and biological features on the day of worst clinical status.

We retrospectively analyzed data of COVID-19 patients (positive SARS-COV-2 RT-PCR) with acute respiratory failure admitted to our hospital between March 1st, 2020 and March 1st, 2021.

Patients were included if (1) they received 15 or more $\mathrm{L} / \mathrm{min}$ of supplemental oxygen for $\geq 6 \mathrm{~h}$ while being hospitalized either in the wards or in ICU and if (2) they

*Correspondence: damien.contou@ch-argenteuil.fr Service de Réanimation Polyvalente, Centre Hospitalier Victor Dupouy, 69, Rue du Lieutenant-Colonel Prud'hon, 95100 Argenteuil, France did not undergo tracheal intubation except for hypoxic cardiac arrest occurring while breathing spontaneously. Patients with a "do-not-intubate" order or still hospitalized were excluded.

Baseline was defined as the day patients met the inclusion criteria. The day of worst clinical status was defined as the day they received the highest oxygen flow with the highest respiratory rate (RR).

Among 161 patients without a "do-not-intubate" order, 49 (30\%, 95\% confidence interval 23-38\%) did not receive invasive mechanical ventilation (Fig. 1). Baseline characteristics and description of the patients on the day of worst clinical status (number of days after hospital admission: 3 [4-6]) are detailed in Table 1. On the day of worst clinical status, the proportion of patients treated with non-invasive ventilation, high-flow nasal cannula and standard oxygen therapy was 8,39 and $61 \%$, respectively. The highest RR was $36[28-40] / \mathrm{min}$ while lowest $\mathrm{SpO}_{2}$ and $\mathrm{PaO}_{2}$ were 91 [90-92] \% and 65 [54-73] mmHg, respectively. Fifteen patients (31\%) had a $\mathrm{RR} \geq 40 /$ min. Median $\mathrm{PaCO}_{2}$ was 37 [34-42] $\mathrm{mmHg}$ and lactate was 1.7 [1.3-1.9] $\mathrm{mmol} / \mathrm{L}$.

On the day of worst clinical status, only 22 (45\%) were hospitalized in ICU (Fig. 1). One of them presented hypoxic cardiac arrest while switching from high-flow nasal cannula to noninvasive ventilation.

Among the 27 (55\%) patients managed in the wards, one $(4 \%)$ was treated with high-flow nasal cannula while 26 (96\%) were treated with standard oxygen therapy alone, with a highest oxygen flow of 15 [15-15] L/min, a highest RR of $32[28-37] / \mathrm{min}$ and a lowest $\mathrm{SpO} 2$ of 91 [91-94]\%.

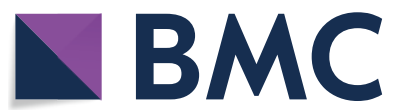

(c) The Author(s) 2021. Open Access This article is licensed under a Creative Commons Attribution 4.0 International License, which permits use, sharing, adaptation, distribution and reproduction in any medium or format, as long as you give appropriate credit to the original author(s) and the source, provide a link to the Creative Commons licence, and indicate if changes were made. The images or other third party material in this article are included in the article's Creative Commons licence, unless indicated otherwise in a credit line to the material. If material is not included in the article's Creative Commons licence and your intended use is not permitted by statutory regulation or exceeds the permitted use, you will need to obtain permission directly from the copyright holder. To view a copy of this licence, visit http://creativecommons.org/licenses/by/4.0/. The Creative Commons Public Domain Dedication waiver (http://creativeco mmons.org/publicdomain/zero/1.0/) applies to the data made available in this article, unless otherwise stated in a credit line to the data. 


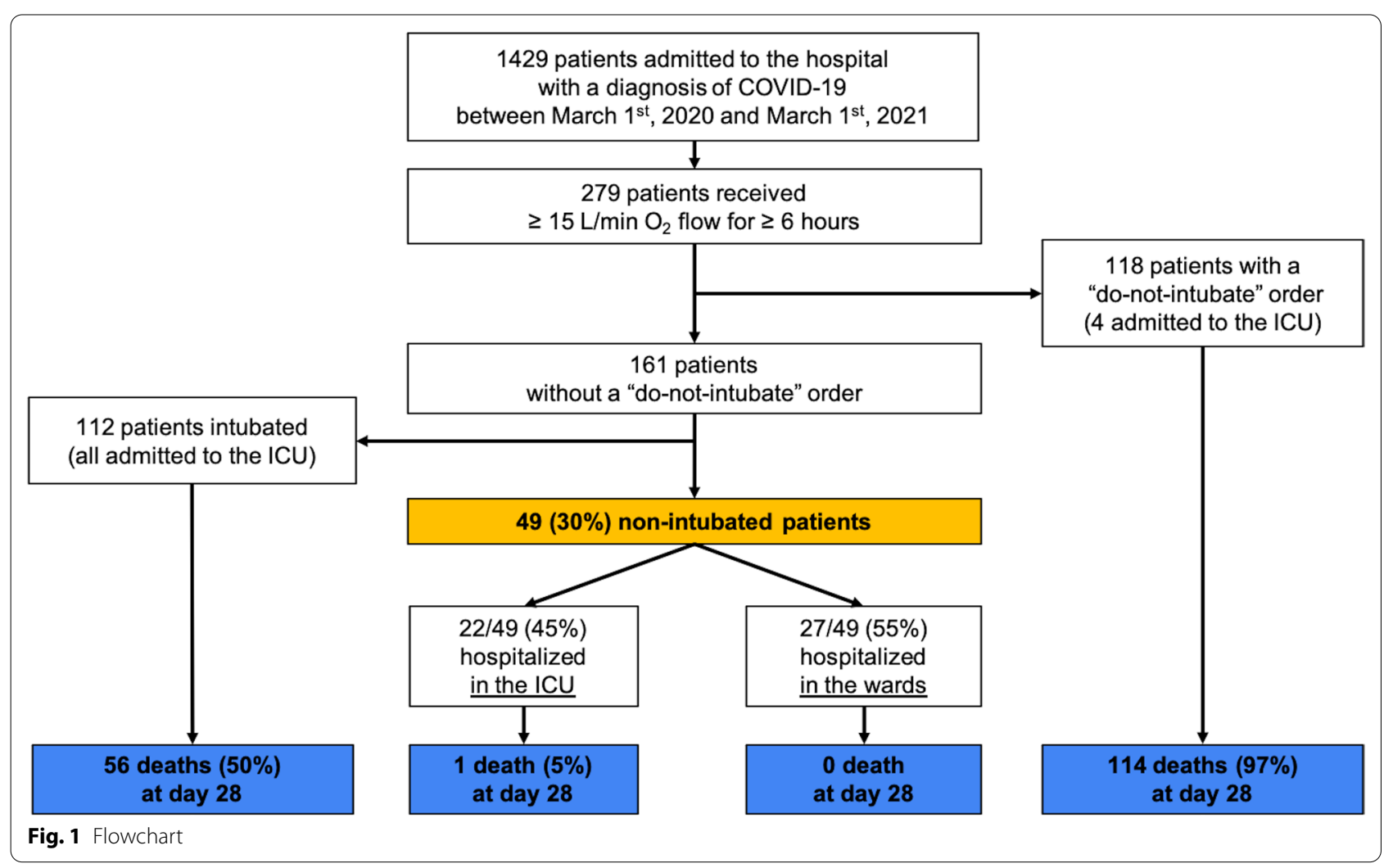

We herein report that $30 \%$ of our patients receiving $\geq 15 \mathrm{~L} / \mathrm{min}$ oxygen flow did not receive invasive mechanical ventilation despite significant tachypnea. Noteworthy, more than half of them were managed outside the ICU without hypoxic cardiac arrest, which could be of interest in a context of a massive inflow of critically ill COVID-19 patients.

Despite one hypoxic cardiac arrest (occurring in a patient cared for in the ICU), avoiding intubation might be feasible in some patients with high levels of supplemental oxygen and significant tachypnea. Rather than predefined $\mathrm{SpO}_{2}$ or $\mathrm{RR}$ thresholds, clinical acumen appears of paramount importance when deciding to initiate invasive mechanical ventilation.

Our results cannot be generalized to other centers nor to any other respiratory diseases than COVID-19. However, this study strengthens the idea that managing non-intubated patients with respiratory failure is a "clinical art" and that individualized patient care is necessary [6]. 
Table 1 Characteristics at baseline and on the day of worst clinical status of 49 non-intubated COVID-19 patients with acute respiratory failure hospitalized in the ICU $(n=22)$ or in the wards $(n=27)$

\begin{tabular}{|c|c|c|c|}
\hline & Total & Patients hospitalized in ICU & $\begin{array}{l}\text { Patients } \\
\text { hospitalized in } \\
\text { the wards }\end{array}$ \\
\hline & $n=49$ & $n=22$ & $n=27$ \\
\hline \multicolumn{4}{|l|}{ Baseline $^{*}$ characteristics } \\
\hline Age (years) & $60[50-66]$ & $63[58-67]$ & $55[46-63]$ \\
\hline Male & $40(82 \%)$ & $17(78 \%)$ & $23(85 \%)$ \\
\hline Diabetes & $15(31 \%)$ & $9(41 \%)$ & $6(22 \%)$ \\
\hline Obesity (BMI > 30 kg/m²) & $16(33 \%)$ & $10(46 \%)$ & $6(22 \%)$ \\
\hline Hypertension & $18(37 \%)$ & $10(46 \%)$ & $8(30 \%)$ \\
\hline Chronic heart failure or coronary artery disease & $3(6 \%)$ & $3(14 \%)$ & $0(0 \%)$ \\
\hline Immunosuppression & $5(10 \%)$ & $3(14 \%)$ & $2(7 \%)$ \\
\hline Charlson comorbidity index & $2[1-3]$ & $3[1-4]$ & $2[0-3]$ \\
\hline SAPS $\|$ & $27[24-30]$ & $28[24-30]$ & $27[22-30]$ \\
\hline Days from hospital admission to baseline & $3[1-4]$ & $2[1-4]$ & $3[2-5]$ \\
\hline Days from symptoms onset to baseline & $9[7-11]$ & $9[8-11]$ & $9[7-11]$ \\
\hline Dexamethasone therapy & $35(71 \%)$ & $16(73 \%)$ & $19(70 \%)$ \\
\hline Antibiotic therapy & $30(61 \%)$ & $10(46 \%)$ & $20(74 \%)$ \\
\hline \multicolumn{4}{|l|}{ Clinical features on the day of worst clinical status } \\
\hline Standard oxygen therapy & $30(61 \%)$ & $4(18 \%)$ & $26(96 \%)$ \\
\hline Maximum oxygen flow (liters per min) & $15[15-15]$ & 20 [15-29] & $15[15-15]$ \\
\hline High-flow nasal cannula & $19(39 \%)$ & $18(82 \%)$ & $1(4 \%)$ \\
\hline Maximum $\mathrm{FiO}_{2}$ & $1[1-1]$ & $1[1-1]$ & 1 \\
\hline Non-invasive ventilation & $4(8 \%)$ & $4(18 \%)$ & $0(0 \%)$ \\
\hline Maximum $\mathrm{FiO}_{2}$ & $1[1-1]$ & $1[1-1]$ & - \\
\hline Highest respiratory rate (/min) & $36[28-40]$ & $38[35-46]$ & $32[28-37]$ \\
\hline Lowest $\mathrm{SpO}_{2}(\%)$ & 91 [90-92] & 90 [86-91] & 91 [91-94] \\
\hline Lowest mean arterial pressure $(\mathrm{mmHg})$ & 90 [82-98] & $91[83-100]$ & 89 [82-96] \\
\hline Highest heart rate (/min) & $92[80-104]$ & $94[82-108]$ & 90 [80-98] \\
\hline Highest temperature $\left({ }^{\circ} \mathrm{C}\right)$ & $37.7[37-38.7]$ & $38.0[37-38.8]$ & $37.5[37-38.2]$ \\
\hline \multicolumn{4}{|l|}{ Biological data on the day of worst clinical status } \\
\hline Leucocytes $\left(/ \mathrm{mm}^{3}\right)$ & $10,150[8175-12975]$ & $11,150[9150-13875]$ & $8850[6600-10475]$ \\
\hline C-reactive protein (mg/L) & $119[34-180]$ & $149[49-296]$ & $115[23-154]$ \\
\hline $\mathrm{pH}$ & $7.46[7.44-7.48]$ & $7.47[7.43-7.48]$ & $7.45[7.44-7.45]$ \\
\hline $\mathrm{PaO}_{2}(\mathrm{mmHg})$ & $65[54-73]$ & $61[52-69]$ & $68[65-102]$ \\
\hline $\mathrm{PaCO}_{2}(\mathrm{mmHg})$ & $37[34-42]$ & 36 [33-40] & $40[38-44]$ \\
\hline Arterial lactate $(\mathrm{mmol} / \mathrm{l})$ & $1.7[1.3-1.9]$ & $1.7[1.3-2.0]$ & $1.4[0.9-1.7]$ \\
\hline Creatininemia ( $\mu \mathrm{mol} / \mathrm{L})$ & $65[57-80]$ & $63[56-80]$ & $66[57-79]$ \\
\hline \multicolumn{4}{|l|}{ Outcomes } \\
\hline Hypoxic cardiac arrest & $1(2 \%)$ & $1(5 \%)$ & $0(0 \%)$ \\
\hline Hospital mortality & $1(2 \%)$ & $1(5 \%)$ & $0(0 \%)$ \\
\hline Duration of high flow oxygen administration** (h) & $82[45-124]$ & $114[58-145]$ & $72[48-122]$ \\
\hline Discharged home with oxygen therapy & $18(37 \%)$ & $5(23 \%)$ & $13(48 \%)$ \\
\hline
\end{tabular}

Continuous variables are reported as medians [quartile 1-quartile 3] and categorical variables are reported as numbers (percentages)

*Baseline was defined as the day patients met the inclusion criteria i.e. received 15 or more $\mathrm{L} / \mathrm{min}$ of supplemental oxygen for $\geq 6 \mathrm{~h}$

**High flow oxygen administration was defined as standard oxygen therapy with a flow of $15 \mathrm{~L} / \mathrm{min}$ or more, or high-flow nasal cannula with $\mathrm{FiO}_{2}$ of 0.80 or more 


\section{Abbreviations}

BMI: Body mass index; SAPS II: Simplified acute physiology score; ICU: Intensive care unit.

\section{Acknowledgements}

We warmly acknowledge Dr Elsa Logre, Dr Olivier Pajot, Dr Jo-Anna Tirolien, Dr Olivia Picq, Dr Florence Sarfati, Dr Paul Desaint, and all the residents who took care of the patients as well as Dr Clara Finck for her writing assistance.

\section{Authors' contributions}

SC, GP, RC and DC are responsible for the conception and design. All the authors took care of the patients. SC is responsible for data acquisition. All the authors were responsible for analysis and interpretation of data. All authors read and approved the final manuscript.

\section{Funding}

No funding.

\section{Availability of data and materials}

The dataset used and analyzed for the current study is available from the corresponding author on reasonable request.

\section{Declarations}

\section{Ethics approval and consent to participate}

Not applicable for a retrospective monocenter observational study. This non-interventional data-based research used the care data collected during patient hospital stay. There is no processing of indirectly identifiable data. Patients and proxies were informed, and written consent was waived.

\section{Consent for publication}

Not applicable.

\section{Competing interests}

The authors declare that they have no competing interests.

Received: 24 March 2021 Accepted: 7 May 2021

Published online: 17 May 2021

\section{References}

1. COVID-ICU Group on behalf of the REVA Network and the COVID-ICU Investigators. Clinical characteristics and day-90 outcomes of 4244 critically ill adults with COVID-19: a prospective cohort study. Intensive Care Med. 2021:47:60-73.

2. Tobin MJ, Laghi F, Jubran A. Why COVID-19 silent hypoxemia is baffling to physicians. Am J Respir Crit Care Med. 2020;202:356-60.

3. Azoulay E, de Waele J, Ferrer R, Staudinger T, Borkowska M, Povoa P, et al. International variation in the management of severe COVID-19 patients. Crit Care. 2020;24:486

4. Oranger M, Gonzalez-Bermejo J, Dacosta-Noble P, Llontop C, Guerder $\mathrm{A}$, Trosini-Desert $\mathrm{V}$, et al. Continuous positive airway pressure to avoid intubation in SARS-CoV-2 pneumonia: a two-period retrospective casecontrol study. Eur Respir J. 2020:56:2001692.

5. Tobin MJ, Laghi F, Jubran A. Caution about early intubation and mechanical ventilation in COVID-19. Ann Intensive Care. 2020;10:78

6. Tobin MJ, Jubran A, Laghi F. Noninvasive strategies in COVID-19: epistemology, randomised trials, guidelines, physiology. Eur Respir J. 2021;57:2004247

\section{Publisher's Note}

Springer Nature remains neutral with regard to jurisdictional claims in published maps and institutional affiliations.
Ready to submit your research? Choose BMC and benefit from:

- fast, convenient online submission

- thorough peer review by experienced researchers in your field

- rapid publication on acceptance

- support for research data, including large and complex data types

- gold Open Access which fosters wider collaboration and increased citations

- maximum visibility for your research: over $100 \mathrm{M}$ website views per year

At $\mathrm{BMC}$, research is always in progress.

Learn more biomedcentral.com/submissions 